\title{
PENGEMBANGAN MODUL PEMBELAJARAN PAI BERBASIS KURIKULUM 2013 DI KELAS V SD NEGERI 21 BATUBASA, TANAH DATAR
}

\author{
Riri Susanti \\ Guru SD Negeri 12 Sungai Jambu, Tanah Datar \\ e-mail: ririsusanti505@gmail.com
}

\begin{abstract}
The problem in this research was the learning of PAI in SD Negeri 21 Batubasa was teacher's center and limited of teaching materials. This study aimed at developing the PAI learning module based on the 2013 curriculum on understanding Allah's Messangers, being simple life and Ikhlas were valid, practical, and effective. This research was a development research using 4-D model (definition, design, development and dissemination). Based on the results, the PAI learning module was very valid with an average of 3.65 based on validator assessment. The module was considered very practical with an average 3.92 based on teacher's ratings and average 3.85 based on student's ratings. The effectiveness of the module on student's learning motivation was in the active category with the average 94.10 and the student's learning activity in the active category with the average 92. The student's learning outcomes above the Minimum Standard Criteria with an average 85.50. It can be concluded that the PAI learning module developed was valid, practical, and effective.
\end{abstract}

Keywords: PAI Learning Module, Curriculum 2013, SD Negeri 21 Batubasa

\section{PENDAHULUAN}

Pendidikan adalah bagian dari suatu proses yang diharapkan untuk mencapai suatu tujuan yang bersifat edukatif serta mampu mendorong dan memotivasi peserta didik dalam melakukan hal-hal yang baik dan bermanfaat. Bahkan orang-orang yang berilmu pengetahuan di dunia fana dimuliakan dan ditinggikan derjatnya sebagai mana firman Allah dalam Surat alMujadillah (58): 11 “Allah akan meninggikan orang-orang yang beriman di antaramu dan orang-orang yang diberi ilmu pengetahuan beberapa derajat...”(Kemenag, 2010).

Melalui kurikulum, pemerintah menjabarkan maksud, fungsi dan tujuan pendidikan nasional. Berdasarkan UUSPN No. 20 Tahun 2003 mengatakan kurikulum adalah seperangkat rencana dan pengaturan mengenai tujuan, isi, dan bahan pelajaran serta cara yang digunakan sebagai pedoman penyelenggaraan kegiatan pembelajaran untuk mencapai tujuan pendidikan tertentu. Di Indonesia telah beberapa kali mengalami perbaikan kurikulum di antaranya kurikulum 1994, kemudian diganti dengan Kurikulum Berbasis Kompetensi tahun 2004. Penerapan KBK pun di sekolah tidak bertahan lama karena pada tahun 2006 pemerintah Indonesia meluncurkan kurikulum baru yaitu Kurikulum Tingkat Satuan Pendidikan (KTSP). Setelah itu pemerintah menetapkan kurikulum baru 
untuk menjawab tantangan globalisasi dengan menetapkan Kurikulum 2013.

Dengan adanya pengembangan kurikulum 2013 ini diharapkan akan menghasilkan insan Indonesia yang produktif, kreatif, inovatif, afektif, melalui penguatan sikap, keterampilan, dan pengetahuan yang terintegrasi. Selain menekankan pada aspek kompetensi, kurikulum 2013 juga menekankan pendidikan karakter. Dalam hal ini, pengembangan kurikulum difokuskan pada pembentukan kompetensi dan karakter peserta didik, berupa paduan pengetahuan, keterampilan, dan sikap.

Kurikulum dalam dimensi proses adalah realisasi ide dan rancangan kurikulum menjadi suatu proses pembelajaran. Proses pembelajaran merupakan proses pengembangan seluruh potensi siswa dan bertujuan agar siswa berhasil menguasai materi sesuai dengan indikator yang ditetapkan. Menciptakan peserta didik yang mandiri dan mampu mengembangkan seluruh potensinya diperlukan keterampilan dan kreatifitas guru dalam menyusun

perencanaan pembelajaran, salah satunya adalah pemilihan sumber belajar. Guru bukan lagi satu-satunya sumber belajar bagi peserta didik. Menurut Sujana sumber belajar adalah segala daya yang dapat dimanfaatkan guru memberikan kemudahan pada seseorang dalam belajarnya (Sujana, 2001). Praswoto mengemukakan sumber belajar adalah segala sesuatu yang berupa benda, data, fakta, ide, orang, dan lain sebagainya yang bisa menimbulkan proses belajar (Prastowo, 2008).

Berdasarkan pendapat di atas maka disimpulkan sumber belajar adalah segala sesuatu yang dapat dimanfaatkan untuk belajar yang memberikan kemudahan bagi seseorang dalam kegiatan belajarnya. Sumber belajar sangat urgen dalam proses belajar mengajar, sebab tanpa adanya sumber belajar dalam proses pembelajaran tidak akan terjadi.

Sumber belajar banyak jenisnya. Adapun sumber belajar menurut Warsita meliputi pesan (massage), orang (people), bahan (material), alat (device), teknik (technique), lingkungan (setting), dan lainnya yang biasa digunakan untuk memberikan kemudahan bagi peserta didik dalam belajar dan menambah pengetahuannya. Adanya sumber belajar, maka siswa mendapatkan fasilitas yang dapat memungkinkannya untuk belajar lebih baik (Warsita, 2008).

Salah satu bentuk sumber belajar berupa bahan (material) adalah berbentuk modul pembelajaran. Purwanto mengemukakan modul adalah bahan belajar 
yang dirancang secara sistematis berdasarkan kurikulum tertentu dan dikemas dalam bentuk satuan pembelajaran terkecil dan memungkinkan dipelajari secara mandiri dalam satuan tertentu (Purwanto, 2007).

Berdasarkan Observasi awal di SD Negeri 21 Batubasa diketahui bahwa pada kegiatan proses pembelajaran Pendidikan Agama Islam (PAI) masih diterangkan dan dicatatkan oleh guru, ini dikarenakan siswa tidak mempunyai sumber belajar berupa buku paket kurikulum 2013 untuk belajar. Selain observasi juga dilakukan wawancara dengan guru PAI, diketahui bahwa "pembelajaran masih bersifat teacher center atau berpusat kepada guru, serta masih kurangnya buku sebagai sumber belajar bagi siswa, guru hanya memberikan materi yang ada pada buku-buku kurikulum KTSP yang berkaitan dengan materi pembelajaran kurikulum 2013. Selain itu guru PAI mengaku bahwa meskipun sudah memasuki semester ke 5 dalam menggunakan kurikulum 2013 tapi masih belum bisa menerapkan pembelajaran dan seutuhnya sesuai Kurikulum 2013" (Suhelti, 2015).

Berdasarkan latar belakang masalah di atas maka peneliti penting melakukan penelitian ini. Penelitiaan ini dilakukan terbatas pada materi Mengenal Rasul Rasul
Allah, Mari Hidup Sederhana dan Ikhlas pada kelas V SD Negeri 21 Batubasa.

\section{BELAJAR}

Menurut Wina Sanjaya bahwa "belajar pada dasarnya adalah suatu proses aktifitas mental seseorang dalam berinteraksi dengan lingkungannya sehingga menghasilkan perubahan tingkah laku yang bersifat positif baik perubahan dalam aspek pengetahuan, sikap maupun psikomotor" (Sanjaya, 2008). Ciri pokok belajar adalah suatu proses perubahan tingkah laku yang terjadi karena adanya usaha yang disengaja dan direncanakan, sehingga seseorang yang belajar akan mendapatkan kecakapan, sikap, kebiasaan, kepandaian, pengetahuan serta keterampilan (Kristiawan, 2014).

Dari pengertian di atas dapat disimpulkan bahwa belajar adalah suatu proses pengumpulan informasi yang diolah menjadi pengetahuan dan pengalaman karena adanya usaha yang disengaja dan direncanakan sehingga menghasilkan kompetensi sikap, pengetahuan, dan keterampilan.

\section{SUMBER BELAJAR DAN BAHAN AJAR}

Sumber belajar dengan bahan ajar merupakan hal yang berbeda, namun sering kali kita kurang jeli mengamati substansi dari masing-masing makna tersebut. Untuk 
itu mengetahui pengertian sumber belajar dan bahan ajar.

\section{Sumber Belajar}

Menurut Association forEducational Communications and Technology (AECT, 1977) sumber pembelajaran adalah "segala sesuatu atau daya yang dapat dimanfaatkan oleh guru, baik secara terpisah maupun dalam bentuk gabungan, untuk kepentingan pembelajaran dengan tujuan meningkatkan efektivitas dan efisiensi tujuan pembelajaran" (AECT, 1977). Sujana mendefenisikan sumber belajar adalah segala daya yang dapat dimanfaatkan guru memberikan kemudahan pada seseorang dalam belajarnya (2001). Praswoto mengemukakan sumber belajar adalah segala sesuatu yang berupa benda, data, fakta, ide, orang, dan lain sebagainya yang bisa menimbulkan proses belajar (2008).

Dari pengertian di atas disimpulkan bahwa sumber belajar adalah segala sesuatu yang dapat dimanfaatkan untuk belajar yang memberikan kemudahan bagi seseorang dalam kegiatan belajarnya.

Sumber belajar terdiri atas beberapa macam, menurut Sudjana dan Rivai (1989) membedakan sumber belajar menjadi enam jenis yaitu: pesan (message), manusia (people), bahan (materials), peralatan (device) sering disebut perangkat keras (hardware), teknik atau metode (technique), lingkungan (setting).

\section{Bahan Ajar}

Menurut Sanjaya bahan ajar adalah segala sesuatu yang menjadi isi kurikulum yang harus dikuasai oleh siswa sesuai dengan kompetensi dasar dalam rangka pencapaian standar kompetensi setiap mata pelajaran dalam satuan pendidikan tertentu Sanjaya, 2008). Sedangkan menurut Praswoto bahan ajar adalah segala bahan (informasi, alat, maupun teks) yang disusun secara sistematis, yang menampilkan sosok utuh dari kompetensi yang akan dikuasai peserta didik dan digunakan dalam proses pembelajaran dengan tjuan perencanaan dan penelaahan implementasi pembelajaran (Praswoto, 2008). Berdasarkan beberapa pendapat di atas, penulis menyimpulkan bahan ajar adalah seperangkat materi pelajaran yang dapat membantu tercapainya tujuan kurikulum yang disusun secara sistematis dan utuh sehingga tercipta lingkungan belajar yang menyenangkan, memudahkan proses pembelajaran.

Bahan ajar menurut bentuknya yaitu bahan ajar cetak, bahan ajar audio, bahan ajar audiovisual, dan bajan ajar interaktif. 


\section{MODUL PEMBELAJARAN}

\section{Pengertian Modul}

Para ahli mengemukakan beberapa pengertian modul secara berbeda namun memiliki makna yang hampir sama. Pengertian modul menurut Kemendikbud adalah bahan ajar cetak yang dirancang untuk dapat dipelajari secara mandiri oleh peserta didik. Modul disebut juga media untuk belajar mandiri karena di dalamnya telah dilengkapi petunjuk untuk belajar sendiri. Artinya, pembaca dapat melakukan kegiatan belajar tanpa kehadiran pengajar secara langsung (Kemendiknas, 2008). Sedangkan modul menurut Daryanto yaitu salah satu bentuk bahan ajar yang dikemas secara utuh dan sistematis, di dalamnya memuat seperangkat pengalaman belajar yang terencana dan didesain untuk membantu peserta didik menguasai tujuan belajar yang spesifik (Daryanto, 2013). Selanjutnya Asyhar mengemukakan modul adalah salah satu bentuk bahan ajar berbantuan cetakan yang dirancang untuk belajar secara mandiri oleh peserta didik. Oleh karena itu modul dilengkapi dengan petunjuk untuk belajar sendiri. Dalam hal ini, peserta didik dapat melakukan kegiatan belajar sendiri tanpa kehadiran pengajar secara langsung (Asyhar, 2011).

Dari beberapa pengertian di atas penulis mengemukakan pengertian modul sebagai berikut, yaitu sebuah bahan ajar yang dirancang secara khusus, sistematis, dan dilengkapi petunjuk yang berisikan pengalaman belajar dengan mengorganisasikan materi pelajaran yang memungkinkan bisa dipelajari secara mandiri maupun terbimbing.

\section{a. Jenis Modul}

Menurut Noah dan Ahmad, pada umumnya modul terdiri atas dua jenis, yaitu modul berbantukan fasilitator dan modul tidak berbantukan fasilitator. sModul berbatukan fasilitator memerlukan fasilitator yang meliputi modul latihan, modul motivasi, dan modul pengembangan kerja. Sementara itu, modul tidak berbantukan fasilitator adalah modul lengkap yang tidak memerlukan bantuan fasilitaor atau guru untuk mempelajarinya. Modul jenis ini meliputi modul pengajaran dan modul akademik (Noah dan Ahmad, 2005).

Selanjutnya, Noah dan Ahmad memberikan penjelasan masing-masing modul sebagai berikut.

1) Modul pengajaran, yaitu modul yang difokuskan pada pembelajaran di sekolah-sekolah rendah, menengah dan juga universitas untuk membantu peserta didik belajar sendiri dalam bidang akademik tanpa bantuan guru.

2) Modul motivasi, yaitu modul yang berisikan berbagai aktivitas, latihan dan 
permainan. Modul ini digunkan oleh guru, fasilitator atau moderator.

3) Modul latihan, yaitu modul berbentuk latihan perkembangan yang diusahan oleh pihak-pihak tertentu untuk meningkatkan kecakapan dalam sebuah organisasi.

4) Modul akademik, yaitu modul yang berkonsep memberikan kemudahan khususnya mahasiswa yang telah ditetapkan oleh universitasnya.

Berdasarkan uraian diatas, dapat disimpulkan bahwa modul dapat dilakukan sesuai dengan kebutuhannya terhadap tujuan yang ingin dicapai. Jika tujuan yang ingin dicapai adalah upaya membantu peserta didik belajar mandiri untuk mengukur sendiri kemampuan belajarnya maka yang diperlukan adalah sebuah modul pembelajaran.

\section{b. Karakteristik Modul Pembelajaran}

Sebuah modul bisa dikatakan baik dan menarik apabila modul yang dikembangkan memenuhi karakteristik sebagai berikut (Kemendiknas, 2008).

1) Self instruksional, melalui modul tersebut seseorang atau peserta didik mampu membelajarkan diri sendiri, tidak tergantung pada pihak lain.

2) Self Contained, seluruh materi pembelajaran dari satu unit kompetensi atau sub kompetensi yang dipelajari terdapat di dalam satu modul secara utuh.

3) Stand Alone, modul yang dikembangkan tidak tergantung pada media lain atau tidak harus digunakan bersama-sama dengan media pembelajaran lain.

4) Adaptive, dikatakan adaptif jika modul dapat menyesuaikan perkembangan ilmu pengetahuan dan teknologi, serta fleksibel digunakan.

5) User Friendly, setiap instruksi dan paparan informasi yang tampil bersifat membantu dan bersahabat dengan pemakainya, termasuk kemudahan pemakai dalam merespon, mengakses sesuai dengan keinginan. Penggunaan bahasa yang sederhana, mudah dimengerti serta menggunakan istilah yang umum digunakan merupakan salah satu bentuk user friendly.

Jadi, dapat disimpulkan bahwa sebuah modul pembelajaran dapat dikatakan sebagai modul yang baik jika peserta didik dapat dengan mudah menggunakannya. Dengan demikian modul pembelajaran harus menggambarkan KD yang akan dicapai oleh peserta didik disajikan dengan menggunakan bahasa yang baik, menarik, dan dilengkapi dengan ilustrasi.

\section{c. Fungsi Modul}

Menurut Daryanto modul berfungsi untuk pembelajaran mandiri (self- 
instruction) artinya pengguna modul dapat belajar kapan saja dan dimana saja secara mandiri (Daryanto, 2013). Selanjutnya Prastowo (2008) mengemukakan bahwa fungsi modul dalam kegiatan pembelajaran adalah Sebagai bahan ajar mandiri, pengganti fungsi pendidik. sebagai alat evaluasi, dan sebagai bahan rujukan bagi siswa.

\section{d. Komponen-Komponen Modul}

Untuk menghasilkan modul pembelajaran yang mampu memerankan fungsi dan perannya dalam pembelajaran yang efektif, modul perlu dirancang dan dikembangkan dengan memperhatikan komponen-komponen modul.

Menurut Sumiati dan Asra (2007) sebuah modul pembelajaran terdiri atas unsur-unsur sebagai berikut :

1) Rumusan tujuan yang diharapkan dapat dikuasai siswa setelah menyelesaikan unit pembelajaran.

2) Deskripsi isi pembelajaran yang harus dipelajari.

3) Kunci lembaran kerja siswa.

4) Lembaran evaluasi/ tes untuk mengukur taraf penguasaan siswa terhadap materi yang dipelajari dan dilengkapi dengan lembar jawaban.

5) Kunci evaluasi yang berisi jawaban yang benar dari setiap soal tes.
6) Petunjuk guru yang berisi petunjuk penggunaan modul.

\section{e. Tahap-Tahap Penyusunan Modul}

Penulisan modul merupakan proses penyusunan materi pembelajaran yang dikemas secara sistematis sehingga siap dipelajari oleh pebelajar. Penyusunan modul belajar mengacu pada kompetensi yang terdapat di dalam tujuan yang ditetapkan. Terkait dengan hal tersebut Kemendiknas (2008) memberikan langkah-langkah penyusunan modul sebagai berikut:

1) Analisis Kebutuhan Modul

2) Penyusunan Draft

3) Uji Coba

4) Validasi

5) Revisi

f. Keunggulan Pembelajaran dengan Modul Keunggulan menggunakan modul adalah pembelajaran lebih terpusat pada kemampuan individu peserta didik, kemudian peserta didik dapat belajar sesuai dengan kecepatan dan mampu melatih diri sendiri.

PEMBELAJARAN

PENDIDIKAN AGAMA ISLAM DAN BUDI PEKERTI

Dalam kurikulum 2013 tidak lagi menggunakan istilah mata pelajaran Pendidikan Agama Islam, tetapi telah 
dirubah menjadi mata pelajaran Pendidikan Agama Islam dan Budi Pekerti. Menurut Alim Pendidikan Agama Islam dan Budi Pekerti dapat diartikan sebagai program yang terencana dalam menyiapkan peserta didik untuk mengenal, memahami, menghayati, hingga mengimani ajaran agama Islam. Serta diikuti tuntunan untuk menghormati penganut agama lain dalam hubungannya dengan kerukunan antar umat beragama, sehingga terwujud kesatuan dan persatuan bangsa (Alim, 2006).

Pelaksanaan Pendidikan Agama Islam dan Budi Pekerti dalam dunia pendidikan memiliki dasar yang sangat kuat adalah sebagai berikut (Alim, 2006).

1. Dasar Yuridis, dasar yuridis formal tersebut terdiri atas: a) Dasar ideal, yaitu dasar falsafah negara Pancasila, sila pertama : Ketuhanan Yang Maha Esa. b) Dasar struktural atau konstitusional, yaitu UUD 1945 dalam Bab XI pasal 29 ayat 1 dan 2.

2. Dasar Religius, yang dimaksud dasar religius adalah dasar yang bersumber dari ajaran Islam. Menurut ajaran Islam, pendidikan agama adalah perintah Tuhan dan merupakan perwujudan ibadah kepada-Nya.

3. Dasar Psikologis, dasar psikologi yaitu dasar yang berhubungan dengan aspek kejiwaan kehidupan bermasyarakat.
Kedudukan Pendidikan Agama Islam dan Budi Pekerti dalam Sistem Pendidikan Nasional (Sisdiknas), mata pelajaran Pendidikan Agama Islam dan Budi Pekerti merupakan mata pelajaran yang wajib ikuti oleh semua peserta didik dalam semua jenjang pendidikan. Mata pelajaran Pendidikan Agama Islam dan Budi Pekerti ini merupakan suatu bentuk penyelenggaraan dalam upaya pencapaian tujuan pendidikan nasional yaitu mengembangkan manusia Indonesia seutuhnya, yakni manusia Indonesia yang beriman dan bertakwa terhadap Tuhan Yang Maha Esa dan berbudi pekerti luhur, mempunyai pengetahuan dan keterampilan, kesehatan jasmani dan rohani, kepribadian yang mantap dan mandiri, serta memiliki rasa tanggung jawab kemasyarakatan dan kebangsaan.

\section{METODE PENELITIAN}

Penelitian ini termasuk penelitian pengembangan atau Research Development. Menurut Trianto (2010) penelitian pengembangan adalah rangkaian proses atau langkah-langkah dalam rangka mengembangkan suatu produk baru atau menyempurnakan produk yang telah ada agar dapat dipertanggungjawabkan.

Dalam penelitian ini, model penelitian pengembangan yang digunakan adalah 
dengan menggunakan model 4D (Four D Model) oleh Triangarajan. Dalam penelitian ini dikembangkan bahan ajar berupa modul pembelajaran yang bermanfaat bagi guru dan siswa dalam proses pembelajaran di Sekolah Dasar (SD). Triangarajan dalam Trianto, mengemukakan bahwa penelitian pengembangan model 4D (Four D Model) dilakukan dengan empat tahap pengembangan, yaitu: Pendefinisian (define), Perancangan (design), Pengembangan (develop), Penyebaran (disseminate) (2009), Berdasarkan rancangan model 4-D, maka langkahlangkah pengembangan modul dapat dilihat dengan bagan berikut.

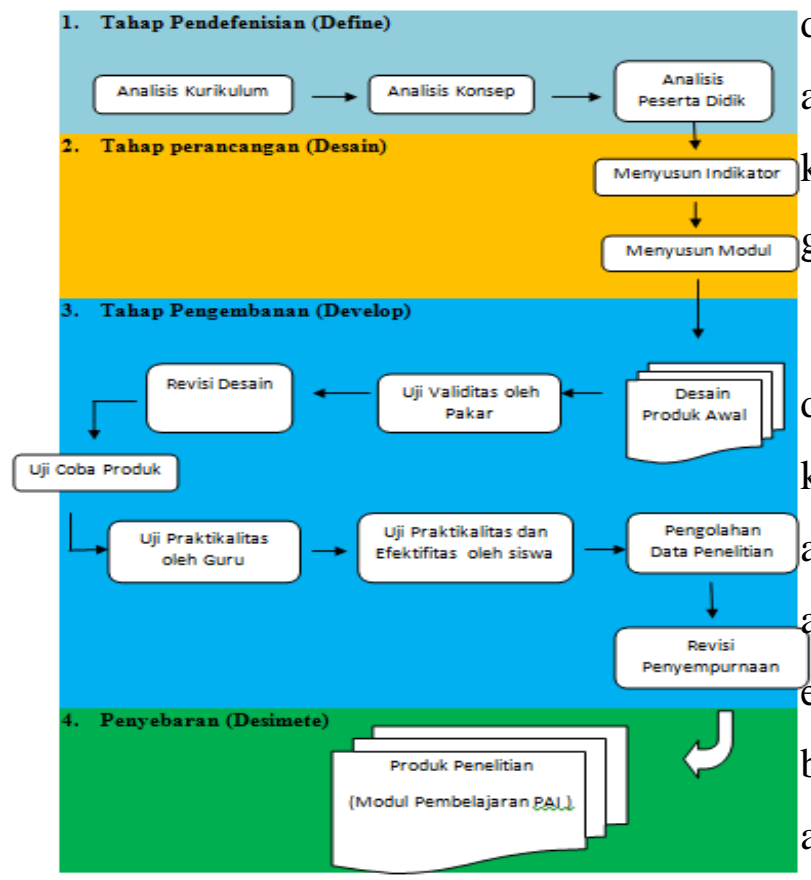

Jenis data pada penelitian ini adalah data kualitatif dan kuantitatif. Data kualitatif berupa analisis hasil wawancara dengan guru. Data kuantitatif diperoleh dari hasil angket validasi ahli, hasil angket praktikalitas dari guru dan siswa, dan observasi yang diberikan kepada observer, serta tes unjuk kerja. Instrumen pengumpulan data terdisi atas observasi , wawancara, angket, tes dan dokumentasi (Arikunto, 2010).

Teknik analisis dalam penelitian ini menggunakan teknik analisis deskriptif. Teknik data deskriptif dilakukan dengan menggunakan statistik deskriptif untuk mendapatkan nilai rata-rata dan persentase. Statistik deskriptif adalah statistik yang digunakan untuk menganalisis data dengan cara mendeskripsikan atau menggambarkan data yang telah terkumpul sebagaimana adanya tanpa bermaksud membuat kesimpulan yang berlaku untuk umum atau generalisasi (Riduan, 2010).

Langkah-langkah yang digunakan dalam analisis data untuk memberikan kriteria kualitas produk yang dikembangkan adalah analisis validitas produk oleh pakar, analisis kepraktisan produk, analisis efektifitas produk dengan analisis motivasi belajar siswa, analisis aktivitas siswa dan analisis hasil belajar (pengetahuan, sikap dan keterampilan). 


\section{HASIL PENELITIAN DAN \\ PEMBAHASAN}

\section{Proses Pengembangan}

\section{a. Tahap Pendefenisian (Define)}

Pada tahap pendefenisian langkahlangkah yang harus dilakukan yaitu analisis kurikulum, analisis konsep, dan analisis siswa.

1) Analisis Kurikulum, yang menjadi acuan adalah kurikulum 2013. Alasan peneliti memilih kurikulum 2013 adalah karena kurikulum ini merupakan kurikulum yang sedang digunakan oleh tempat terlaksananya uji coba produk. Materi yang dipilih adalah Mari Mengenal Rasul Rasul Allah, Hidup Sederhana dan Ikhlas.

2) Analisis konsep bertujuan untuk menentukan isi, merincikan dan merumuskan konsep-konsep utama yang akan dipaparkan. Berdasarkan analisis terhadap kurikulum 2013 ditetapkan 4 konsep yang akan dicantumkan didalam modul sebagai materi. Keempat konsep tersebut memiliki sub judul, konsep pertama 5 sub judul, konsep kedua 3 sub judul, konsep ketiga 4 sub judul, dan konsep keempat 6 sub judul.

3) Analisis peserta didik, Analisis ini bertujuan untuk mengetahui karakteristik peserta didik yang menjadi subjek penelitian. Siswa yang menjadi subjek penelitian adalah siswa kelas V (lima) SD Negeri 21 Batubasa yang memiliki usia 10-12 tahun. Menurut Piaget dalam Tohirin (2005), anak dalam usia ini telah memahami operasi logis dengan bantuan benda-benda konkrit. Kemampuan ini terwujud dalam memahami konsep kekekalan, kemampuan untuk mengklasifikasikan dan serasi, mampu memandang suatu objek dari sudut pandang yang berbeda secara objektif. Anak pada tahap ini sudah cukup matang untuk menggunakan pemikiran logika, tetapi hanya objek fisik yang ada saat ini (karena itu disebut tahap operasional konkrit). Disimpulkan dari analisis siswa bahwa siswa kelas V SD Negeri Batubasa dengan umur berkisar antara 10 sampai 12 tahun memiliki latar belakang dan karakteristik yang bervariasi.

\section{b. Tahap Perancangan (Design)}

Modul dibuat dengan Microssoft Office dan Microsoft Publiser dengan jenis tulisan Comic Sans MS ukuran ukuran 13 dengan warna yang bervariasi. Hasil perancangan modul pembelajaran Pendidikan Agama Islam (PAI) meliputi cover, kata pengantar, daftar isi, petunjuk penggunaan modul, kompetensi, peta konsep, materi, refleksi, rangkuman, lembar kerja siswa, kunci jawaban, evaluasi, glossarium, dan daftar pustaka. 


\section{c. Tahap Pengembangan (Develop)}

Tahap pengembangan meliputi validasi dan uji coba modul untuk melihat validitas, praktikalitas, dan efektifitas modul yang dikembangkan.

\section{1) Validasi Modul}

Modul yang telah disusun, divalidasi oleh 3 orang validator. Validasi modul dilakukan oleh 3 orang pakar yang sesuai dengan bidang kajiannya yaitu Dr. Muhammad Kristiawan,M.Pd,

Dr. praktikalitas guru dengan pratikalitas siswa Suharmon, M.A, dan Dr. Fadriati, M.Ag. Rata-rata validasi modul pembelajaran Pendidikan Agama Islam (PAI) dan Budi Pekerti secara keseluruhan adalah 3,65 dengan kategori sangat valid. Hasil validisi RPP dengan rata-rata validasi secara keseluruhan adalah 3,52 dengan kategori sangat valid. Hasil validasi Instrumen tes yang dirancang adalah sangat valid. Dari hasil validasi dan Instrumen tes menunjukkan bahwa modul, RPP dan instrumen tes yang dirancang sangat valid. Hal ini berarti modul pembelajaran, RPP dan istrumen tes yang dirancang sudah sangat baik dan dapat digunakan sebagai sumber belajar bagi siswa dan pelaksanaan penilaian bagi guru.

\section{2) Praktikalitas modul}

Penilaian praktikalitas dilakukan oleh guru dan siswa. Modul dikatakan praktis apabila modul tersebut dapat membantu guru dalam proses pembelajaran dan bagi siswa dapat mempermudah dalam pemahaman materi yang dikembangkan. Tingkat kepraktisan terhadap modul yang diisi oleh guru dengan rata-rata 3,92 berada dalam kategori sangat praktis. Tingkat kelayakan terhadap modul yang diisi oleh s is w a dengan 97,64 dan ratarata 3,85 dengan kategori sangat praktis

Dapat disimpulkan bahwa rata-rata dengan kategori sangat praktis. Hal ini berarti penampilan bahan ajar berupa modul pembelajaran Pendidikan Agama Islam (PAI) dan Budi Pekerti menarik untuk dipelajari. Materi yang disajikan memiliki tampilan gambar yang mendukung dan menarik. Dengan demikian, secara umum modul pembelajaran Pendidikan Agama Islam (PAI) dan Budi Pekerti yang dihasilkan sudah praktis dan mendapat respon yang baik dari siswa.

\section{3) Efektifitas Modul}

Penilaian efektivitas dilakukan dengan melihat motivasi belajar siswa, aktivitas belajar siswa, dan penilaian hasil belajar (sikap,kognitif dan psikomotor).

Tingkat motivasi belajar siswa berada pada kategori sangat tinggi (sangat efektif) dengan rata-rata 9,41. Tingkat aktifitas siswa dengan rata-rata sebesar 92 dengan kategori aktif sekali. Penilaian hasil belajar 
kognitif menunjukkan kategori efektif dengan rata-rata 85,50 karena KKM (75) yang diterapkan oleh sekolah sudah dicapai, dengan rata-rata kelas sudah berada di atas KKM. Penilaian aspek sikap spiritual siswa, maka diperoleh rata-rata 3,36 dengan kategori sangat baik. Sedangkan aspek keterampilan diperoleh rata-rata 3,66 dengan kategori sangat baik.

\section{d. Penyebaran (disseminate)}

Tahap penyebaran modul masih pada tahap skala terbatas, penyebaran modul pembelajaran Pendidikan Agama Islam (PAI) dan Budi Pekerti masih terbatas pada kelas V (lima) SD Negeri 21 Batubasa yang menjadi subjek penelitian dengan jumlah siswa 15 orang.

\section{Pembahasan}

Dalam penelitian ini, validasi modul dilakukan oleh 3 orang validator ahli. Menurut Peraturan Pemerintah Nomor 19 Tahun 2005 tentang Badan Standar Nasioal Pendidikan (BSNP), pasal 43 ayat 2 yang menyatakan bahwa validasi modul menyangkut empat aspek, yaitu kelayakan isi (materi), kelayakan penyajian, kelayakan bahasa, kelayakan kegrafikaan dan kelayakan gambar. Berdasarkan hasil analisis terhadap angket validasi oleh ahli, secara umum menyatakan bahwa modul pembelajaran Pendidikan Agama Islam
(PAI) dan Budi Pekerti sudah sangat valid, dengan rata-rata nilai sebesar 3,65. Menurut Trianto (2010) valid berarti bahwa penilaian sudah memberikan informasi yang akurat tentang bahan ajar yang dikembangkan.

Hasil penilaian validator yang menyatakan bahwa, materi dalam modul sudah sesuai dengan kurikulum yang berlaku (Kurikulum 2013), dapat mendukung pemahaman konsep, membantu siswa mengkonstruksi pengetahuannya, serta dapat meningkatkan efektifitas dalam pembelajaran, sehingga baik digunakan sebagai bahan ajar dalam pembelajaran Pendidikan Agama Islam (PAI) dan Budi Pekerti. Perolehan kategori sangat valid juga didukung oleh penelitian Festiyed dalam Elfitriani (2010) yaitu tampilan modul yang menarik dengan banyak gambar dan objek yang sesuai dengan tuntunan materi, akan meningkatkan ketertarikan siswa terhadap materi pembelajaran.

Jadi, hasil validasi bahwa modul pembelajaran pada materi Mari Mengenal Rasul Rasul Allah, Hidup Sederhana dan Ikhlas yang dihasilkan telah teruji dan telah dinyatakan valid sesuai dengan Peraturan Pemerintah Nomor 19 Tahun 2005 tentang Badan Standar Nasioal Pendidikan (BSNP) . Oleh sebab itu, hasil dari validasi ini dapat dipertanggung jawabkan. 
Menurut Arikunto dan Cepi (2008) praktikalitas merupakan aspek yang dapat menentukan suatu instrumen mudah digunakan, praktis, dan tidak rumit. Berdasarkan analisis data praktikalitas guru dan siswa modul pembelajaran ini tergolong sangat praktis. Kepraktisan modul ini juga didukung oleh hasil penelitian Alfianika dkk (2014), yang menyatakan kepraktisan modul itu tergambar dari dua aspek, yaitu kemudahan dan kesesuaian.

Dari aspek kemudahan dalam penggunaan tergambar bahwa modul mudah digunakan oleh guru dan siswa. Ini berarti bahwa modul yang dikembangkan dapat membantu dan memudahkan guru dalam memberikan penjelasan yang benar terhadap konsep-konsep pembelajaran dan peran guru dapat berubah dari seorang pengajar menjadi fasilitator dalam pembelajaran. Serta secara keseluruhan modul pembelajaran ini disenangi dan bisa dimengerti oleh siswa.

Hal ini didukung dengan penelitian Alfianika (2014) bahwa dengan menggunakan siswa bisa belajar dengan mudah walaupun tidak ada guru dan siswa bisa belajar di mana saja. Dari aspek kesesuaian dengan waktu tergambar bahwa modul yang dirancang telah sesuai dengan waktu yang ditetapkan.
Dari hasil peneitian di atas penggunaan modul pembelajaran PAI telah dapat meningkatkan motivasi belajar siswa. Hal ini sesuai dengan pendapat Mc. Donald dalam Sardiman (2011) menyatakan "motivation is an energy change within the person characterized by effective arousal and anticipatory goal reaction" Motivasi merupakan perubahan energi yang terjadi dalam diri seseorang yang ditandai dengan munculnya efektif dan reaksi untuk mencapai tujuan. Hampir semua siswa V (lima) SD Negeri 21 Batubasa merasa senang belajar dengan menggunakan modul pembelajaran.

Selain itu Allah juga mengingatkan manusia agar hidup dengan penuh motivasi, sebagaimana yang terdapat dalam AlQur'an Surat Ar-Ra'd (13): 11 "Sesungguhnya Allah tidak merobah Keadaan sesuatu kaum sehingga mereka merobah keadaan yang ada pada diri mereka sendiri" (Q.S Ar-Ra"d (13) : 11(Kemenag RI, 2010).

Allah mengajarkan manusia untuk melakukan perubahan. Perubahan yang lahir dari sebuah motivasi individu yang kemudian motivasi tersebut merubah cara pandang dan aktivitas. Maknanya, bahwa sebuah motivasi akan mengawali sebuah perubahan dan merubah cara pandang dan kinerja individu ataupun kelompok. 
Melalui modul pembelajaran Pendidikan Agama Islam (PAI) dan Budi Pekerti berbasis kurikulum 2013, siswa dapat lebih aktif dalam pembelajaran. Ini terlihat dari keikutsertaan dan keterlibatannya selama proses pembelajaran, seperti ikut bertanya dalam diskusi dan memberikan respon pada pertanyaan teman. Hal ini didukung oleh pendapat Setiawan dalam Danisa (2015) mengungkapkan pengkonstruksian pengetahuan secara bersama-sama melalui diskusi kelompok memungkinkan siswa dapat mengungkapakan gagasan, mendengarkan pendapat orang lain dan secara bersamasama membangun pengertian. Kegiatan diskusi menjadikan siswa berpikir dan dapat melatih kemampuan kognitifnya.

Jadi, dapat disimpulkan bahwa pembelajaran menggunakan modul PAI dan Budi Pekerti telah dapat meningkatkan aktivitas belajar siswa sesuai dengan pendapat Kemp dkk dalam Rahmi (2015), menyatakan " aktivitas siswa dalam pembelajaran dapat dilihat berdasarkan dari keikutsertaan dan keterlibatannya dalam memberi respon".

Trianto (2010) mengemukakan "tes hasil belajar merupakan butir tes yang digunakan untuk mengetahui hasil belajar siswa setelah mengikuti kegiatan pembelajaran. Menurut Depdikbud tahun
1996 dalam Trianto, "Setiap siswa dikatakan tuntas belajarnya (ketuntasan individual) jika proporsi jawaban benar siswa $\geq 65 \%$ dan suatu kelas dinyatakan tuntas belajarnya (ketuntasan klasikal) jika dalam kelas tersebut terdapat $\geq 85 \%$ siswa yang tuntas belajarnya. Dengan demikian dapat disimpulkan bahwa pembalajaran dengan menggunakan modul pembelajaran Pendidikan Agama Islam (PAI) dan Budi Pekerti berbasis kurikulum 2013 secara individual dan klasikal dinyatakan tuntas dan tergolong pada kategori efektif karena $90 \%$ siswa mencapai KKM.

Dapat disimpulkan penggunaan modul pembelajaran PAI dan Budi Pekerti dapat meningkatkan hasil belajar siswa. Hal ini sesuai dengan pendapat Depdikbud tahun 1996 bahwa ketuntasan belajar telah lebih dari $85 \%$.

Keberhasilan dalam belajar juga tidak lepas dari petunjuk yang diberikan oleh Allah Swt. sebagaimana yan terdapat dalam surat Al-Baqarah (2) : 31-33"dan Dia mengajarkan kepada Adam Nama-nama (benda-benda) seluruhnya, kemudian mengemukakannya kepada Para Malaikat lalu berfirman: "Sebutkanlah kepada-Ku nama benda-benda itu jika kamu mamang benar orang-orang yang benar!"mereka menjawab: "Maha suci Engkau, tidak ada yang Kami ketahui selain dari apa yang 
telah Engkau ajarkan kepada kami; kurikulum 2013 untuk siswa kelas V SD

Sesungguhnya Engkaulah yang Maha Negeri Batubasa. Berdasarkan mengetahui lagi Maha pengembangan yang telah dilakukan,

Bijaksana[35]."Allah berfirman: "Hai diperoleh kesimpulan sebagai berikut:

Adam, beritahukanlah kepada mereka Nama-nama benda ini." Maka setelah diberitahukannya kepada mereka Namanama benda itu, Allah berfirman: "Bukankah sudah Ku katakan kepadamu, bahwa Sesungguhnya aku mengetahui rahasia langit dan bumi dan mengetahui apa yang kamu lahirkan dan apa yang kamu sembunyikan?"(Kemenag RI, 2010).

Dari uraian di atas dapat kita ambil kesimpulan bahwa proses dalam pembelajaran menentukan prestasi belajar. Setiap peserta didik mempunyai perbedaan dalam prestasi belajar.Ada yang cenderung tinggi, ada pula yang cenderug rendah. Prestasi belajar adalah hasil yang dicapai seeorang setelah ia melakukan perubahan belajar baik di sekolah maupun di luar sekolah. Dalam proses pembelajaran, prestasi belajar dapat diketahui melalui evaluasi belajar yang dilakukan pendidik kepada peserta didik melalui berbagai macam-macam evaluasi

\section{KESIMPULAN}

Penelitian ini merupakan penelitian pengembangan modul pembelajaran pada materi Mengenal Rasul-rasul Allah, Mari Hidup Sederhana dan Ikhlas berbasis

1. Modul pembelajaran Pendidikan Agama Islam (PAI) dan Budi Pekerti termasuk kategori sangat valid dengan rata-rata 3,65 berdasarkan penilaian validator.

2. Modul pembelajaran Pendidikan Agama Islam (PAI) dan Budi Pekerti termasuk kategori sangat praktis dengan rata-rata 3,92 berdasarkan penilaian guru dan rata rata 3,85 berdasarkan penilaian siswa. Kemudian modul pembelajaran Pendidikan Agama Islam (PAI) dan Budi Pekerti termasuk kategori sangat efektif ditinjau dari motivasi siswa dengan ratarata 94,10 , aktivitas belajar siswa dengan rata-rata 92 termasuk kategori aktif sekali, dan hasil belajar siswa dengan rata-rata 85,50 .

Penelitian pengembangan ini telah menghasilkan modul pembelajaran pada pembelajaran Pendidikan Agama Islam (PAI) dan Budi Pekerti. Pada dasarnya penelitian ini juga dapat memberikan gambaran dan masukan khususnya kepada penyelenggara pendidikan (kepala sekolah dan guru Pendidikan Agama Islam (PAI) karena dapat meningkatkan kualitas pembelajaran PAI. Selain itu, dapat membuat pembelajaran PAI menjadi 
menyenangkan serta dapat dijadikan indikator untuk meningkatkan hasil belajar siswa.

\section{DAFTAR PUSTAKA}

Al-Qur'an dan Terjemahan

Alfianika, Ninit, Atmazaki, dan Abdurahman. (2014). Pengembangan Model Modul Pembelajaran Bahasa Indonesia Berbasis Investigasi Kelompok (Group Investigation) Pada Materi Menulis Karangan Ilmiah Siswa Kelas Xi Sma $N 8$ Padang, Universitas Negeri Padang: Jurnal Bahasa, Sastra dan Pembelajaran Volume 2 Nomor 2, Juni 2014

Arikunto, Suharsimi dan Cepi Safruddin Jabar. (2008). Evaluasi Program Pendidikan: Pedoman Teoritis Praktis Bagi Mahasiswa dan Praktisis Pendidikan. Jakarta: Bumi Aksara.

Asyhar, Rayandra. (2011). Kreatif Mengembangkan Media Pembelajaran, Jakarta: Gauang Persada Perss.

Danisa, Valent Sari, Suciati, dan Widha Sunardo. (2016). Pengembangan Modul Berbasis Brain Based Learning disertai Vee Diagram untuk Meningkatkan Hasil Belajar Kognitif, diakses tanggal 22 Juli 2016.

Daryanto. (2013). Penyusunan Modul (Bahan Ajar untuk Persiapan Guru dalam Mengajar). Yogyakarta: Gava Media.

Depdiknas. (2008). Penulisan Modul, Jakarta: Ditjen PMPTK.

Elfitriani. (2012). Pengembangan Modul Pembelajaran Biologi Berorientasi Konstruktivisme Dilengkapi Mind Map
Pada Materi Sistem Eksresi Untuk Sekolah Menengah Atas. Tesis Universitas Negeri Padang

Kristiawan, M. (2014). A Model for Upgrading Teachers Competence on Operating Computer as Assistant of Instruction. Global Journal of HumanSocial Science Research, 14(5).

Noah, Sidek Mohd dan Jamaludin Ahmad. (2005). Pembinaan Modul: Bagaimana Membina Modul Latihan dan Modul Akademik, Malaysia University Putra Malaysia.

Peraturan Menteri Pendidikan dan Kebudayaan Nomor 66 Tahun 2013 tentang Standar Penilaian Pendidikan.

Prastowo, Andi. (2012). Panduan Kreatif Membuat Bahan Ajar Inovatif. Yogyakarta: Diva Press.

Purwanto, Pengembangan Modul. Jakarta: Bumi Aksara.

Riduwan. (2012). Skala Pengukuran Variabel-Variabel Penelitian, Bandung: Alfabeta.

Rahmi, Lailatur. (2015) Modul Pembelajaran dan Instrumen Penilaian Pada Materi Pelestarian Lingkungan Hidup dan Pembangunan Berkelanjutan Berbasis Kurikulum 2013 untuk Siswa Kelas XI IPS. Tesis Universitas Negeri Padang.

Sanjaya, Wina. (2008). Kurikulum dan Pembelajaran. Jakarta: Kencana.

Sardiman, A.M. (2011). Interaksi dan motivasi belajar mengajar. Jakarta: PT Raja Grafindo Persada.

Siddik, Muhammad. (2015). Urgensi Sumber Belajar dalam Pendidikan, Jurnal Pendidikan, diakses tanggal 3 Desember 2015. 
Sudjana, N. (2001). Teknologi Pengajaran. Bandung Sinar Baru.

Sumiati dan Asra. (2007). Metode Pembelajaran. Bandung: CV. Wahana Prima.

Tohirin. (2005). Psikologi Pembelajaran Pendidikan Agama Islam, Jakarta: Raja Grafindo Persada.

Trianto. (2010). Pengantar Pendidikan Bagi Pengembangan Profesi dan Tenaga Kependidikan. Jakarta: Kencana Prenada Media Group.

Undang-undang Nomor 20 tahun 2003 Tentang Sistem Pendidikan Nasional. 
JMKSP

Jurnal Manajemen, Kepemimpinan, dan Supervisi 